\title{
Planning And Pricing Of Financial Services: A Study On Perceptions And Practices Of Non-Banking Finance Companies
}

M. R. Shollapur, Siddaganga Institute of Technology, India

\begin{abstract}
The financial services industry in India is expanding and heading for global competition. The market players need to frame a well thought customer oriented product planning and pricing strategy with a commitment to add value to customers in the volatile and competitive environment. This study elicits the responses of major players in the industry and offers inputs for acquiring competitive capabilities in planning and pricing financial services.
\end{abstract}

Keywords: Financial services, Non-banking finance companies, Loan, company, Hirepurchase \& leasing company, Investment companies, Housing finance companies, Residuary non banking companies, Product differentiation, Customer's needs, Customer satisfaction, Price determinants, Cost effectiveness.

\section{INTRODUCTION}

ndia is the second largest country in the world measured by population. The economy of India is currently
the world's fourth largest in terms of real GDP, after USA, China and Japan and the second fastest growing
economy in the world, averaging at annual growth of 7.1 percent. The IMF estimates show that by 2007, India will be the third largest economy in the world, overtaking the Japanese economy. The service sector has proved India's most dynamic sector in recent years. The fact that service sector now accounts for more than half of the GDP probably makes a watershed in the evolution of the Indian economy. While almost all services participated in the boom, growth is faster in communication and financial services, in particular. The rate of annual growth in financial services exceeds aggregate annual growth in services. Key data on percentage share of service sector's contribution to GDP and average annual growth in total services as well as financial services are presented in Table 1. In this background, Indian financial sector deserves special mention in the global context. The US \$28 billion market has grown at around 15 percent and has displayed stability for the last several years, even when other markets in the Asian region were facing a crisis. The financial sector is set to witness emergence of financial super markets providing a suite of services from retail to corporate banking and industrial lending to investment banking. A tremendous scope exists even for banking and non-banking financial institutions from other countries. Top companies from United Kingdom and United States, among others are already active in India's financial markets. Some of the big names are Merrill Lynch, Openheimer, J.P. Morgan, Morgan Stanley, Grindlays, Standard Charterd, Hongkong and Shamghai Banking Corporation, among others. Foreign institutional investors (FIIs) have been allowed to invest in the stocks and securities markets with rights of full repatriation and withdrawal. Their presence has added new dynamics to the financial markets in India. In the background of the Indian financial sector integrating with the global environment, planning and pricing of financial services by the indigenous players becomes a challenging task.

\section{PREPARING A CASE FOR NBFCs}

A Non-Banking Finance Company (NBFC) is a company registered under the Indian Companies Act of 1956 and is engaged in the business of loans and advances, acquisition of shares/stocks/bonds/debentures/securities issued by government or local authority, leasing, hire-purchase, insurance business, and chit business. The NBFCs such as a equipment leasing company, a hire-purchase company, a loan company, investment company, or a 
residuary non-banking company, are registered with RBI. To obviate dual regulation, certain categories of NBFCs, which are regulated by other regulators, are exempt from the requirement of registration with the Reserve Bank of India (RBI). These include venture capital funds, merchant banking companies, stock broking companies registered with Securities and Exchange Board of India (SEBI), insurance company holding a valid Certificate of Registration issued by Insurance Regulation and Development Authority (IRDA), nidhi companies as notified under Section 620A of the Companies Act, 1956, chit companies as defined in clause (b) of section 2 of the Chit Funds Act, 1982 or housing finance companies regulated by National Housing Bank. Though they are doing functions akin to that of banks, they cannot accept demand deposits, and cannot be a part of the payment and settlement system.

NBFCs in India began in a small way in the 1960s to serve the needs of the savers and investors whose financial needs were not adequately covered by the existing banking system in India. The NBFCs began to invite fixed deposits from investors and worked out leasing deals for the larger industrial firms. In the early decades, their operations were on a limited scale and could not make a significant impact on the financial system. However, between the 1980s and 90s, the NBFCs were well entrenched and began to attract a large number of investors. Owing to their customer friendly reputation, the NBFCs became highly competitive.

On the basis of their legal status, the NBFCs have been classified as unincorporated firms, unregistered companies, registered companies without RBI certification and the certified NBFCs. Based on their principal activity the RBI has classified the NBFCs into these categories: a) Loan Company, b) Hire Purchase Finance Company, c) Equipment Leasing Company, d) Investment Company, and e) Residuary Non-banking Company. The scope of the NBFCs is fast growing with the multiplication of financial services. Some of the NBFCs are also engaged in underwriting through subsidiary units, and by offering allied financial services including stock broking, investment banking, asset management, and portfolio management. The NBFCs largely complement the banking system. Their efficiency in financial services and organizational flexibility helps them build a large body of clientele, including small borrowers and bigger corporate establishments.

The last two decades have witnessed a phenomenal growth of NBFCs. The number of such companies which stood at 7,063 in 1981 increased to 25,085 in 1991 and further to 39,454 in 1995, recording a compound growth rate of 14 percent per annum. In the last 10 years, deposits with NBFCs have grown tenfold. The same for scheduled commercial banks have comparatively increased 4.6 times only. Further, in the areas of mobilization and utilization of funds, as well as earnings-position, the performance of the NBFCs is equally impressive. A study of leasing and hire-purchase companies by the ICICI has revealed that the ratio of profits to total working funds was 4.73 per cent as compared with 1.04 percent for private sector banks and 0.24 percent for public sector banks. The ratio of net interest income earned to total income was 40.2 percent for NBFCs as compared to 29.9 percent for private sector banks. Thus, by the end of the 1990s, the NBFCs had attained significant heights in their coverage and area of activity. They continued to attract larger number of retail customers and provided attractive sops. This record of comparative performance has obviously evinced interest in us for an analytical study in the context of the changing environment.

\section{STATEMENT OF THE PROBLEM}

The process of economic reforms and liberalization (1991) in India has given a boost to the financial service industry. A number of non-baking financial institutions have also emerged to provide a variety of financial services in India to meet the different funding requirements of the corporate sector in the changing environment. A number of innovative financial products and services such as credit cards, consumer finance, scripless trading of shares, mutual funds, credit rating, venture capital, factoring, leasing, merchant/investment banking, etc. have been introduced that have got integrated with the Indian financial system. Thus, the scope of financial services is expanding and the industry is heading for competition. Competition for NBFCs has mainly emerged from the new private sector banks and foreign banks. The competitive environment is augmented by deregulation of interest rates, easy accessibility to capital market, relaxation of entry norms and the entry of new firms in the financial service sector including the multinationals. Customers are also becoming more demanding. They prefer those firms which supply innovative and quality services at the right price with safety, convenience and speed. This intensified the competition in the finance sector and consequently influenced the marketing process of the NBFCs. Among others, the product planning and pricing assume an integral aspect of strategic perspective. 
The offering of financial products is the raisin deter of NBFCs. These financial products collectively constitute a key element in the marketing mix of NBFCs. An NBFC which cannot deliver a need satisfying product(s) has no reason to exist. The competition has led the business of financial services from margin to volume. The narrow operating margin would imply that NBFCs have a tough time in framing their pricing strategy. Therefore, they have to be able to influence the volume of business as well as generate profits. For this purpose NBFCs need to understand the requirements of their customers, design financial products as required, price them competitively and offer them through fast and economical channels. In view of different categories of customers, there is a need to develop special relationships with customers and focus on market differentiation. Hence, NBFCs are compelled to frame a well thought customer oriented product planning and pricing strategy with a commitment to add value to customers. This approach enables NBFCs legitimize their presence amidst volatile, and competitive environment. Against this background, a need is felt to examine the perceptions and practices of the NBFCs in planning and pricing of their financial products.

\section{OBJECTIVES}

The study aimed to fulfill the following objectives:

1. trace the unique features of financial products offered by NBFCs

2. study the product differentiation techniques adopted

3. examine the customer satisfying strategies and the feedback mechanism

4. identify the forms and determinants of price of financial products.

5. study the objectives of the pricing policy

6. elicit the NBFCs' perception on price as a strategic weapon

7. $\quad$ trace the cost-effectiveness of the financial services offered

\section{METHODOLOGY}

The study includes a survey of 50 NBFCs operating in Karnataka state (India). The distribution of NBFCs on the basis of their nature of business includes 20 General Finance Companies (GFCs), 13 Hire-Purchase and Leasing Companies (HPLCs), seven Investment Companies (ICs), five Housing Finance Companies (HFCs) and five others (OTHs) which cover the residuary NBFCs. A convenient sampling technique was adopted for selecting the NBFCs. The study is based on the primary data collected through administering a common questionnaire. The data are analyzed by making use of percentages with reference to the industry, as a whole, as well as with reference to each segment in the industry. The questions on factors considered while fixing prices, and objectives of pricing were set to seek the ranking (1-5) of NBFCs. Hence this data is presented (Table 4) in the form of priority accorded to the underlying factors as a whole without giving segmentwise break-ups.

The paper is organized into three sections: an overview of NBFCs covered in the study, discussion on NBFCs' perceptions and practices relating to planning and pricing of financial services, and conclusion.

\section{NBFCS COVERED IN THE STUDY: AN OVERVIEW}

Financial services offered by NBFCs include fund-based as well as fee-based services. In fund-based services, the NBFCs raise equity, debt, and deposits and invest in securities or lend to the needy. In fee-based services, they enable others to raise capital from market or exchange financial assets and risk with other participants of the market. NBFCs covered in this study are fund-based service providers. An over view of these organizations is presented hereunder:

\section{General Finance Companies}

In states like Karnataka, a typical NBFC called as Finance Corporation/ Loan Company is popular. They have a thin capital base which is normally less than Rs.1 lakh. Their main source of fund is deposits collected from public at attractive rates of interest. They make loans to wholesale traders, retailers, small scale industries and employed persons who do not either approach commercial banks or who are denied credit facilities by the latter. The 
rate of interest charged by them is as high as $24 \%$. Yet, the borrowers prefer these units due to easy availability of funds without procedural hassles. These NBFCs borrow from money market as well as capital market. They raise chit funds, purchase and discount hundis, and discount post-dated cheques. Thus they create a link between longterm and short-term interest rates.

\section{Hire-purchase and Leasing Companies}

Hire purchase is a mode of financing the price of the goods to be sold on a future date. The goods themselves serve as security until the loan is fully cleared. Hire purchase finance companies help small and transport operators, farmers and professionals to buy equipments on the basis of hire purchase. The bulk of the hire purchase credit goes to commercial vehicles for the road transport industry. They are relatively developed and organized in south India.

Leasing business though very common in western countries is new to India. In a leasing business the user of capital equipment (i.e. an investor) does not buy the product himself but only buys the use of it against payment on a monthly rental fee to a leasing company which owns the product. Leasing has proved to be a popular financing method for acquiring plant and machinery, especially by small and medium sized enterprises.

Most leasing companies in India combine leasing with hire purchase financing. Both leasing and hirepurchase have emerged as a supplementary source of intermediate to long-term finance. The business of leasing and hire-purchase is highly competitive with too many players in the market. The Industrial Credit and Investment Corporation of India ( ICICI), the Industrial Reconstruction Corporation of India (IRCI), the State Industrial and Investment Corporation of Maharashtra Limited ( SISCOM), the Karnataka State Industrial Development Corporation (KSIDC), the Gujarat Industrial and Investment Corporation ( GIIC), TVS Group, State Bank of India (SBI), the National Insulated Cable and the United Commercial Bank, the Motor and General Finance Company, the Punjab National Bank (PNB), the Sundram Finance Limited, the MGF Limited, the Goodwill India Limited, and the New India Insurance Limited are the important players in the hire-purchase and leasing segment in India. In vehicle financing, in particular, Ashok Layland Finance Company, SR Truck Finance, Kotak Mahindra, Escorts Financial Services Limited, Mobile Finance are prominent players.

\section{Investment Companies}

These are the financial institutions whose principal business is the acquisition of securities. For this purpose, they collect funds from generally the household savers, through specific financial instruments (unit/share/debenture) and invest these pooled funds in suitable securities. In general, the basic objective of such investment companies is to get enhanced benefits of huge and pooled resources through low risk and expertise. The major investment companies in India include investment trusts, mutual funds, and common trust funds of commercial banks, management investment companies, and unit trusts.

\section{Housing Finance Companies}

Institutions which provide loans to individuals and societies specially for constructing houses and flats come in this category. The assistance is also provided for repairs and renovation, extension, addition, alteration of existing houses, They offer specific schemes for corporate bodies, promoters and developers. The responsibility to provide housing finance in India largely vested with the Government till the early eighties. The setting up of National Housing Bank (NHB) in 1988 as the apex housing institution was the beginning of the emergence of housing finance as a funds-based financial service. Later, various public and private institutions entered into this field with different housing finance schemes to cater to the housing needs of the individuals and institutions. The other prominent players include HUDCO (Housing and Urban Development Corporation), Housing Development Finance Corporation (HDFC), Ind Bank Housing, Citi Bank, Dewan Housing Finance, insurance and banking organizations in the public, private and joint sectors. 


\section{Others}

The companies not coming under any one particular category are included in this category. They are popularly known as Residuary Non-Banking Companies (RNBCs).

The mushroom growth of NBFCs has also caused many unhealthy developments in the financial system. Realizing the importance of these institutions, the government has initiated regulations relating to compulsory registration, capital adequacy norm and mandatory credit rating to ensure discipline in their operations.

\section{NBFC'’ PERCEPTIONS AND PRACTICES: A DISCUSSION}

The discussion on product planning and designing covers issues such as unique features of financial products, product differentiation techniques, strategy of satisfying customers' needs, development of innovative services, and feedback on customers' satisfaction. In case of pricing strategy, the issues such as form of price and its determinants, objectives of pricing, availability of close substitutes, price as a strategic weapon, and cost effectiveness of financial services are considered.

\section{Features of financial products}

Financial products include an array of financial services which the NBFCs offer with antecedent conditions. Customers prefer those products which offer benefits and satisfy their needs. In addition, they favour those products which are easily accessible to them without delay and cost. The customers avail of these products as long as they satisfy their requirements and expectations. It is, therefore, imperative on the part of the NBFCs to rightly perceive those attributes in their offering that help achieve a wider reach out without forsaking safety of funds. In financial products, the safety and security of funds is a primary consideration. In addition, NBFCs are obliged to ensure value addition to their customers. The financial products should enable customers achieve longterm growth and prosperity. These product features create a favorable image in the minds of customers. Hence, there is a need to trace the features of financial products offered by the NBFCs.

Table 2 (Sl.No.1) shows that a majority (29\%) NBFCs consider those financial products which reassure safety and security of their funds. They want their money involved in product offering to be safe and secured. It is needless to emphasize that the institutions dealing with funds ought to give thought to safety and security. $27 \%$ NBFCs want their products to contribute to the long-term growth of the customers. The benefit of financial products should not extinguish soon; they must result in creating a long-term stream of benefits to the user groups. 25\% NBFCs desire their financial products to be within the reach of their customers. In other words, customers should not find it difficult to approach NBFCs for seeking suitable financial products. The remaining NBFCs (19\%) want their financial products to enable value addition to their customers. This is realizable by offering them at the competitive and affordable prices as well as helping customers improve their financial position consequent on the use of their financial products. The safety and security aspect of the funds tied up in a given financial product is endorsed by all NBFCs except HPLCs. These companies wish to offer the financial products that enable customers to achieve long-term growth.

\section{Product Differentiation Techniques}

In the competitive market, product differentiation is a sine quo non for creating an identity for a company distinct from its competitors. It helps create market niches. This is realized through customized service offering on the basis of specific needs of the customers. Further, improving the quality of service delivery may be considered for this purpose. It includes all aspects of the manner in which the service is delivered to the customers. NBFCs can offer a package of services in one go by bundling together the interrelated financial services. Tata Finance, for example, has set its sight on providing a range of financial services under one umbrella. Delivering the services to the door steps of the customers also strengthens the distinctive character of the product.

Table 2 (Sl.No.2) reveals that a majority NBFCs (36\%) has adopted a strategy of offering personalized services to create product differentiation. Customers' needs for financial products are unique. As a result, offering 
personalized financial products assume significance in the financial service industry. $31 \%$ NBFCs believe in improved service quality, $18 \%$ accept providing financial products at the door steps of customers and the others (15\%) find it worthwhile to add package of benefits to customers that can distinguish from its competitors. Barring GFCs, all the players in the industry acknowledge offering personalized service as a key to product differentiation. GFCs, however, accord priority on improving service quality for earning a distinct image in the competitive industry. Investment companies are providing services at customers' door-steps.

\section{Strategy of Satisfying Customers' Needs}

NBFCs need to evolve a suitable strategy to maximize customers' satisfaction by catering to their needs. This goes a long way in earning and retaining customers' patronage. In case of Birla Global Finance Limited, for example, a person availing a car loan also buys a mutual fund unit and insurance cover. The customer obviously feels that he is being offered what he wants. Normally the strategies of satisfying customers include market penetration, market development, product development and product diversification.

Market penetration strategy considers satisfying the present needs of present customers by maintaining quality, service delivery, and commitment. Increasing the current range of financial products is one way to increase the business of existing financial products in the existing markets. Market penetration also includes attracting competitor's customers. The overlapping nature of financial services and the deregulation of interest rates have enabled NBFCs to attract competitors' customers. Secondly, market development strategy enables NBFCs to fulfill current needs of new customers. For this purpose, NBFCs have to outreach themselves to those customer segments which are hitherto uncovered by using appropriate promotional strategies. Thirdly, product development strategy focuses on satisfying new needs of the present customers. As the customers' needs change over time, NBFCs need to modify the existing offerings, create financial products with different attributes, and develop altogether new financial products. Housing finance companies, for example, can offer additional financial products meant for expansion of existing structures as well as for repairs and furnishing to those who have already obtained financial assistance. Lastly, product diversification strategy considers satisfying new needs of the new customers. Since it involves the marketing of new and generally unrelated offerings to new markets, it is relatively a risky proposition.

Table 2 (Sl.No.3) reveals that a majority of NBFCs (38\%) has adopted market penetration strategy. They are complacent in satisfying the present needs of present customers by maintaining quality, and promoting service delivery. 24\% NBFCs use product development strategy with a view to fulfill current needs of new customers by modifying the existing offerings, creating financial services with different attributes, and developing altogether new financial products. It is, thus, evident that the NBFCs have focused more on the existing customers. In reaching out new customers, $21 \%$ NBFCs emphasize on current needs, whereas $15 \%$ NBFCs have considered satisfying the new needs of new customers. The segmentwise analysis reveals that each player in the service industry has strongly favored satisfying the current needs of the present customers. The strategies adopted by GFCs, and HFCs fall in line with the strategies of the Industry as a whole. The HPLCs and ICs have given second priority to satisfying the current needs of the new customers. They are found to be relatively more exploratory in reaching untapped market segments. A majority of residuary NBFCs consider satisfying the current needs of the present as well as new customers.

\section{Development of Innovative Products}

NBFCs operate in a dynamic environment. Given the significant changes taking place in financial services industry, NBFCs ought to be responsive to changes, and develop innovative financial products by introducing of something new in their existing offering. For this purpose, NBFCs have to develop a futuristic approach and look out for the needs of the customers. Offering of products with attributes compatible to market is facilitated by continuous lookout for the needs of the customers. Kotak Mahindra Finance Limited, for instance, came out with innovative K-Card which is a hybrid product, a cross between a credit card and a loan. An NBFC which cannot develop new products would eventually exit from the market.

Table 2 (Sl.No.4) shows that 48\% NBFCs are undertaking the development of new financial products whereas the other half is not making any attempt. This tends to affect their long-term presence in the financial 
service industry. The segmentwise analysis reveals that HPLCs, ICs and OTHs are developing innovative products. A majority of GFCs and HFCs are not developing innovative financial products.

\section{Bases of Innovative Ideas}

NBFCs can generate new product ideas on the basis of external cues obtained from their competitors. At times, they can undertake opinion survey of their existing customers and seek new insights from them for designing new products. Similarly, focus group sessions may also be organized for in-depth and interactive discussion on innovative ideas. In a professionally run NBFCs, field based market research shall be undertaken to gain new knowledge of customers and their environment.

Table 2 (Sl.No.5) reveals that a majority NBFCs (42\%) undertakes opinion surveys as well as formal market research (37\%) for obtaining new ideas. About 20\% NBFCs get cues from their competitors' operations and a few companies (2\%) organize focus group sessions. The responses of all segments except GFCs fall in line with the Industry's overall observations. A majority GFCs find market research as a basis for their innovative ideas. However, HFCs have not undertaken any market survey for gaining innovative ideas.

\section{Feedback on Customers' Satisfaction}

The product strategy of NBFCs in the competitive environment would be complete only after obtaining the customers' feedback on their product offerings. Feedback may be obtained either by inviting suggestions directly from customers or conducting customer surveys. Customer satisfaction can also be measured against benchmarks of the best market practices, if any. NBFCs can also setup a customer complaints and grievances cell for this purpose.

Table 2 (Sl.No.6 \& 7) shows that 90\% NBFCs seek feedback from their customers on their product offering. Of these, 52\% NBFCs invite suggestions from their customers, $26 \%$ undertake customer surveys and $21 \%$ obtain information from their complaints and grievances cell. The priority accorded by each NBFC regarding the modes of ascertaining customer satisfaction is in conformity with the aggregated preferences of NBFCs. Except OTHs, none of the NBFCs has adopted benchmarks in ascertaining their customer satisfaction.

\section{Form of Price}

Price is a complex and multi-faceted issue in marketing. Price set by NBFCs as a consideration for their products is instrumental in determining their revenue, profits and overall competitiveness. Customers expect NBFCs to be transparent and unambiguous in their pricing. Hence, the details of price including its form and amount must be carefully communicated to customers. The form of price depends on the type of the financial products delivered. It may be in the form of interest (charge for use of money) in case of general loan companies/hire purchase and leasing companies; fees in case of professional and consultancy service companies; and brokerage/commission in case of investment management services. However, the price is constrained by the governmental regulations, size of funds involved in financial products, the policy of NBFCs, the prevailing rates in the economy and the intensity of competition.

Table 3 (Sl.No.1) shows that a majority NBFCs (66\%) levy the price in the form of interest. The forms of price include commission and brokerage in case of about 12\%-13\% NBFCs. A very few NBFCs collect their price in the form of fees. Segmental analysis reveals that interest continues to be a major form of price in each category. Whereas commission is the second important form of price with GFCs, HFCs, and OTHs, brokerage is an important form with HPLCs and ICs. The percentage of NBFCs (HPLCs and OTHs) reporting fees as a form of price is small.

\section{Price Determinants}

Various factors such as cost, competitor's price, income size of the target customers etc. are considered in determining the price of the financial products. The costs incurred on providing and promoting financial products serves as the floor under which the price must not go. In addition, NBFCs cannot overlook the competitors' price. Without knowing the competitors' prices, NBFCs are bound to be vulnerable to the competitors sooner or later. 
Similarly, the ability of the target customers to pay the price needs special attention. Even the customer's sentiments, favorable feelings about the service offerings, company image, etc. cannot be overlooked in pricing decisions. In case of pricing of new financial services it is more complex and challenging as cost, demand, competitive response etc. are relatively unfamiliar.

Table 4 (Sl.No.1) reveals that the NBFCs perceive that the cost incurred in offering and promoting financial products is a strong price determinant. The competitors' prices as well as the customers' psychology are the other factors influencing the price. A few NBFCs find the income of the target customers as an influencing factor. Effective cost management by NBFCs can take care of the market competition as well as create a favorable image in the market.

\section{Objectives of Pricing}

The long-term survival of NBFCs is an important one. In times of economic or competitive difficulty, the primary objective of pricing may simply be to survive. It necessitates the company to adjust price levels with a view to generate more revenue to match expense. Earning the profits is the reason for NBFCs coming into being. It compels them to trade-off between price to be charged for their financial products and cost incurred thereon. Enlarging the market share can also be an objective of the pricing as the price facilitates an increase in the sale of financial products. An NBFC is compelled to adjust price levels relative to its competitors so as to increase its market share. Last but not the least, pricing is instrumental in generating customer satisfaction. It is important that the pricing objectives be consistent with the objectives of other elements of marketing mix.

Table 4 (S1.No.2) reveals that 32\% NBFCs accord a top priority on customer satisfaction and 30\% NBFCs consider 'survival' as an important objective of pricing. Interestingly, earning profits is their third preference which is endorsed by $22 \%$ NBFCs. A few (12\%) NBFCs perceive pricing as an instrument to increase their market share.

\section{Availability of Close Substitutes}

Competition is heightened in the contemporary financial products industry as there a number of players. The existence of substitutes in the industry influences the pricing of financial services in the form of a ceiling on the price. Hence a need to know the NBFCs' awareness of the close substitutes available in the market.

Table 3 (Sl.No. 2) reveals that a great majority (76\%) of NBFCs find close substitutes in the market and hence find an intense competition in the market. Among the industry players GFCs, HPLCs, and OTHs have the availability of close substitutes. The response of these players far exceeds the industry as a whole. As a result, NBFCs capable of offering the best financial products at the most competitive prices can survive in the market. This capability is reflected in an NBFC being a price leader or a follower. When an NBFC is able to exert considerable influence over competitors, it can assume the role of a price leader. This influence is often a reflection of a dominant market share. On the other hand, it can imitate the price set by other NBFCs. Hence, there is a need to know the NBFCs' perception regarding the influence of competitive environment on their pricing practices.

Table 3 (Sl.No.3) shows that a majority of NBFCs (52\%) has found a large number of aggressive competitors whom they follow in pricing their financial products. About $48 \%$ have found themselves as the price leaders. A great majority of GFCs and HPLCs have found themselves as price leaders. The response of ICs and HFCs is equally divided between 'price follower' and 'price leader.' A majority of OTHs have found themselves as price followers.

\section{Price as a Strategic Weapon}

Pricing affects many parties, including employees, shareholders, competitors and the public at large. It has a deep impact on the image of the products as well as on economic performance of the NBFCs. Price is used as a missile in combating market rivalry. In addition, it promotes and prevents the entry and exit of the firms in/from the financial service industry. Further, it is used to successfully differentiate financial products and create a favorable image for NBFCs. 
Table 3 (Sl.No.4) reveals that a majority of NBFCs (33\%) perceive price as an image-index of the NBFCs. $30 \%$ NBFCs have found price as a measure of product differentiation in the industry to build a unique image for the company. $23 \%$ found price as a tactical weapon in managing the market rivalry in the short-run, and a few (10\%) found it as a barrier to new entrants in the industry. The response of ICs and OTHs are almost similar to the opinion of the industry. Whereas majority GFCs find price as a product differentiation technique, majority HPLCs finds price as an entry barrier.

\section{Strategies of Cost Effectiveness}

Cost is a strong determinant of price of financial products, and hence the NBFCs need to initiate suitable measures to be cost effective in their operations. This includes raising the financial resources at the competitive rates, utilizing the physical and human resources effectively, maintaining a small but clean business, computerizing the operations and laying off the excess manpower wherever necessary. This helps them achieve cost effectiveness and earn a large market share.

Table 3 (Sl.No.5) reveals that a majority NBFCs (43\%) has perceived raising of low-cost funds as an appropriate route to cost effectiveness. $26 \%$ prefer to maintain a small business and the remaining prefers computerization of operations and the lay-off for achieving cost effectiveness. The opinion of GFCs and HPLCs fall in line with the overall opinion of the industry. Whereas ICs find maintaining a small business as a key to cost effectiveness, OTHs find computerizing the operations an appropriate strategy for this purpose.

\section{CONCLUSION}

It is evident from the preceding discussion that the NBFCs in India have attached a considerable importance to safety and security of their funds as well as the long-term growth of their customers. Product differentiation is more typical of the present day financial service industry. NBFCs have tried to be distinct by offering personalized services as well as improving service quality. They have adopted comprehensive techniques such as opinion survey of existing customers and formal market research for eliciting ideas on innovative products. Open suggestions are also invited on how can these NBFCs perform in a satisfying manner. Interest as a form of price is popular with NBFCs and the 'cost' continues to strongly influence their pricing. They have also considered the competitors' price while determining the price of their financial products. It is interesting to note that their commitment to customers' satisfaction precedes the objective of survival. A majority NBFCs has accepted the presence of large and aggressive competitors in the financial service industry. They perceive price as an index of image as well as a technique of product differentiation. The NBFCs believe in raising funds at lower costs so as to achieve cost effectiveness in their operations. The reduction in interest rates in the economy as a whole will help NBFCs to access the resources at low costs. However, the analysis reveals the following constraints in planning and pricing of the financial services:

1. The NBFCs are considering more of the current needs of the existing as well as new customers. There is enough scope for exploring the untapped requirements of their customers and catering to these new needs. With the booming middle class in India, they can design new financial products in addition to financing automobiles and consumer durables. Thus, they have enough scope for innovative financial products.

2. Low entry barriers have led to mushroom growth of the industry. Majority NBFCs have close substitutes in the market and have a large number of aggressive competitors. They have to draw new insights from this phenomenon while planning and pricing their financial products. In addition, they have to also consider the customers' psychology while designing the pricing strategy in particular.

3. In a bid to satisfy the customers, the NBFCs have overlooked the survival criterion. They appear to be overambitious that tends to cause setbacks to NBFCs. Unregulated competition in the mobilization of term deposits has already led to interest wars and has caused failure of some non-banking companies. Therefore, NBFCs have to observe business considerations in their operations.

4. Technological developments such as ATM networks and Internet have made commercial banks more impersonal in their dealings. Therefore NBFCs can take advantage of this lacuna of banks especially for promoting personal loans, commercial vehicle finance which require a strong customer relationship. Further, NBFCs can position themselves based on the needs of different groups of customers. The industry 
should keep itself fine-tuned to the environmental changes in general and sophisticated client needs in particular.

5. NBFCs can consider offering different financial services such as leasing, housing finance, merchant banking, etc. under one roof. This is necessitated due to the entry of financial sector conglomerates in the Indian economy. Tata Finance, for example, which focused on vehicle financing, is setting one stop shop for a range of financial products under one umbrella. Besides, it has forged alliances with the other entities: a credit card venture with American Express, a housing finance venture with Abbey National Plc; a stock broking outfit with TD Waterhouse Group Inc., and a money changing service again with American Express. It is a high time for other NBFCs to consider offering a range of products under one roof.

These suggestions go a long way in infusing a strategic perspective in marketing financial products. This perspective offers inputs to new thinking, new approaches and new skills for acquiring competitive ability that can boost up NBFCs' financial performance in the competitive financial service industry.

\section{AUTHOR INFORMATION}

Dr. M R Shollapur is professor and director of Postgraduate Department of Management Studies and Research Centre, Siddaganga Institute of Technology, Tumkur, Karnataka (India). He holds a first class master's degree in commerce (M Com), Business Administration (MBA), and Ph.D. in banking and finance. He has served for 27 years in teaching in collegiate and university including Karnataka University, Dharwad and Marshall University, Huntington (USA). Dr. Shollapur has completed two funded research projects, guided 4 Ph.Ds and 2 M.Phils. His publications include five books and 47 papers. His areas of interest include accounting, banking and finance.

\section{REFERENCES}

1. Batra, G.S. and Bhatia, B.S. 1995. Management of Financial Services. Deep and Deep Publications: New Delhi.

2. Bhole, L.M. 1992. Financial Institutions and Markets. Tata McGraw Hill Publishing Company Ltd: New Delhi.

3. Desai Vasant.1994. Development Banking. Himalaya Publishing House: Bombay.

4. $\quad$ Khan, M. Y. 1997. Financial Services, Tata McGraw Hill Publishing Co.: New Delhi.

5. Pandey, I. M. 1996. Specialised Financial Services Institution: Policy \& Strategic Issues. Paper presented in National Seminar on Financial Services - The Changing Scenario organized by Dr. B. R. Ambedkar Open University, March 15 - 16, 1997.

6. $\quad$ Poonam Kumar. 1996. NBFCs: To Weather Challenges, Chartered Financial Analyst, December.

7. Preeti,S.K., 2000. Financial Service-Gearing up to Meet the Challenges of the New Millennium in Raghavachari and Ramani (Ed), Delivering Service Quality, Macmillan India Limited: New Delhi.

8. Ranjan, Das. and Raveendra, C. 2004, Whither NBFCs'Strategic Marketing, Vol III Issue V, SeptemberOctober.

9. Reidenbach, E. R. and Pitts, R. E. 1986. Bank Marketing: A Guide to Strategic Planning, A Reston Book, Englewood Cliffs, N.J.

10. Shah, A.C. 1996. Finance Companies-Problems and Prospects. Economic and Political Weekly, Vol. XXXI, No. 12

11. Thakkar, M. Deora, R.S. and Agarwal, J.A., 1998. Cap on NBFCs: Stringent But Late?, The Economic Times, January 13

12. Vijay Kumar, B. 1996. Strategic Directions for NBFCs. Paper presented in National Seminar on Financial Services - The Changing Scenario organized by Dr. B. R. Ambedkar Open University, March 15 - 16, 1997.

\section{Websites:}

1. $\quad$ http://www.indiabudget.nic.in

2. http://www.google.com

3. http://www.adexta.com 
4. $\quad$ http://www.edu.com

5. http://www.opera.com

6. http://www.thinkstrategic.biz

7. $\quad$ http://www.indianbussiness.nic.in/india-profile/bkg.html

8. http://mitpress.mit.edu/catalog/item/default.asp?tid=10109\&ttype $=2$

Table 1: Service Sector and GDP in India

\begin{tabular}{|l|c|c|c|c|c|c|}
\hline \multirow{2}{*}{ Particulars } & \multicolumn{3}{|c|}{ \% Share in GDP } & \multicolumn{3}{c|}{ Average Annual Growth Rate (\%) } \\
\cline { 2 - 8 } & $\mathbf{1 9 8 0 - 8 1}$ & $\mathbf{1 9 9 0 - 9 1}$ & $\mathbf{2 0 0 0 - 0 1}$ & $\begin{array}{r}\mathbf{1 9 5 0 - 5 1} \\
\mathbf{1 9 8 0 - 8 1}\end{array}$ & $\begin{array}{c}\mathbf{1 9 8 0 - 8 1} \\
\mathbf{1 9 9 0 - 9 1}\end{array}$ & $\begin{array}{c}\mathbf{1 9 9 0 - 9 1} \\
\mathbf{2 0 0 0 - 0 1}\end{array}$ \\
\hline 1. Total Services & 37.1 & 40.5 & 48.1 & 4.5 & 6.6 & 7.5 \\
\hline 2. Financial Services & 2.4 & 4.2 & 7.0 & 7.2 & 11.0 & 10.0 \\
\hline
\end{tabular}

Source: “Understanding India's Service Revolution” J. Gordan and P. Gupta (Adapted)

Table 2: Planning of Financial Products - NBFCs' Perceptions

\begin{tabular}{|c|c|c|c|c|c|c|c|c|}
\hline \multirow[b]{2}{*}{ SI No } & \multirow{2}{*}{$\begin{array}{l}\text { Key issues in } \\
\text { product } \\
\text { planning and } \\
\text { designing }\end{array}$} & \multirow[b]{2}{*}{ Underlying aspects } & \multirow[b]{2}{*}{ Total } & \multicolumn{5}{|c|}{ Segmentwise responses } \\
\hline & & & & GFCs & HPLCs & ICs & HFCs & OTHs \\
\hline \multirow{8}{*}{1} & \multirow{8}{*}{ Product features } & a. Convenience & $\begin{array}{c}24 \\
(25.00)\end{array}$ & $\begin{array}{c}9 \\
(30.00)\end{array}$ & $\begin{array}{c}5 \\
(18.52)\end{array}$ & $\begin{array}{c}4 \\
(28.57)\end{array}$ & $\begin{array}{c}3 \\
(27.27)\end{array}$ & $\begin{array}{c}3 \\
(21.43)\end{array}$ \\
\hline & & $\begin{array}{l}\text { b. Safety and security of } \\
\text { funds }\end{array}$ & $\begin{array}{c}28 \\
(2917)\end{array}$ & $\begin{array}{c}10 \\
(3333)\end{array}$ & $\begin{array}{c}7 \\
(2593)\end{array}$ & $\begin{array}{c}4 \\
(28.57)\end{array}$ & $\begin{array}{c}3 \\
(2727)\end{array}$ & $\begin{array}{c}4 \\
(28.57)\end{array}$ \\
\hline & & c. Value addition to & 18 & 3 & 6 & & & 4 \\
\hline & & customers & $(18.75)$ & $(10.00)$ & $(22.22)$ & $(14.29)$ & $(27.27)$ & $(28.57)$ \\
\hline & & $\begin{array}{l}\text { d. Enable Long-term growth } \\
\text { of customers }\end{array}$ & $\begin{array}{c}26 \\
(27.08)\end{array}$ & $\begin{array}{c}8 \\
(26.67)\end{array}$ & $\begin{array}{c}9 \\
(33.33)\end{array}$ & $\begin{array}{c}4 \\
(28.57)\end{array}$ & $\begin{array}{c}2 \\
(1818)\end{array}$ & $\begin{array}{c}3 \\
(2143)\end{array}$ \\
\hline & & e. Others & 0 & 0 & 0 & 0 & 0 & 0 \\
\hline & & & $(00)$ & $(00)$ & $(00)$ & $(00)$ & $(00)$ & $(00)$ \\
\hline & & Total & $\begin{array}{c}96 \\
(100)\end{array}$ & $\begin{array}{c}30 \\
(100)\end{array}$ & $\begin{array}{c}27 \\
(100)\end{array}$ & $\begin{array}{c}14 \\
(100)\end{array}$ & $\begin{array}{c}11 \\
(100)\end{array}$ & $\begin{array}{c}14 \\
(100)\end{array}$ \\
\hline \multirow{8}{*}{2} & \multirow{8}{*}{$\begin{array}{l}\text { Product } \\
\text { differentiation } \\
\text { techniques }\end{array}$} & $\begin{array}{l}\text { a. Offering personalized } \\
\text { services }\end{array}$ & $\begin{array}{c}28 \\
(35.90)\end{array}$ & $\begin{array}{c}6 \\
(27.27)\end{array}$ & $\begin{array}{c}11 \\
(42.30)\end{array}$ & $\begin{array}{c}4 \\
(44.44)\end{array}$ & $\begin{array}{c}4 \\
(44.45)\end{array}$ & $\begin{array}{c}3 \\
(25.00)\end{array}$ \\
\hline & & b. Improving the service & 24 & 12 & 6 & 1 & 2 & 3 \\
\hline & & quality & $(30.77)$ & $(54.55)$ & $(23.07)$ & $(11.11)$ & $(22.22)$ & $(25.00)$ \\
\hline & & $\begin{array}{l}\text { c. Adding package of } \\
\text { benefits }\end{array}$ & $\begin{array}{c}12 \\
(15.38)\end{array}$ & $\begin{array}{c}3 \\
(13.63)\end{array}$ & $\begin{array}{c}4 \\
(15.39)\end{array}$ & $\begin{array}{c}0 \\
(00)\end{array}$ & $\begin{array}{c}2 \\
(22.22)\end{array}$ & $\begin{array}{c}3 \\
(25.00)\end{array}$ \\
\hline & & d. Providing services at & 14 & 1 & 5 & 4 & 1 & 3 \\
\hline & & $\begin{array}{l}\text { the door steps of } \\
\text { customers }\end{array}$ & $(17.95)$ & $(4.55)$ & (19.24) & $(44.45)$ & (11.11) & $(25.00)$ \\
\hline & & e. Others & $\begin{array}{c}0 \\
(00) \\
\end{array}$ & $\begin{array}{c}0 \\
(00) \\
\end{array}$ & $\begin{array}{c}0 \\
(00) \\
\end{array}$ & $\begin{array}{c}0 \\
(00) \\
\end{array}$ & $\begin{array}{c}0 \\
(00) \\
\end{array}$ & $\begin{array}{c}0 \\
(00) \\
\end{array}$ \\
\hline & & Total & $\begin{array}{c}78 \\
(100) \\
\end{array}$ & $\begin{array}{c}22 \\
(100) \\
\end{array}$ & $\begin{array}{c}26 \\
(100) \\
\end{array}$ & $\begin{array}{c}9 \\
(100) \\
\end{array}$ & $\begin{array}{c}9 \\
(100) \\
\end{array}$ & $\begin{array}{c}12 \\
(100)\end{array}$ \\
\hline
\end{tabular}


Table 2: continued

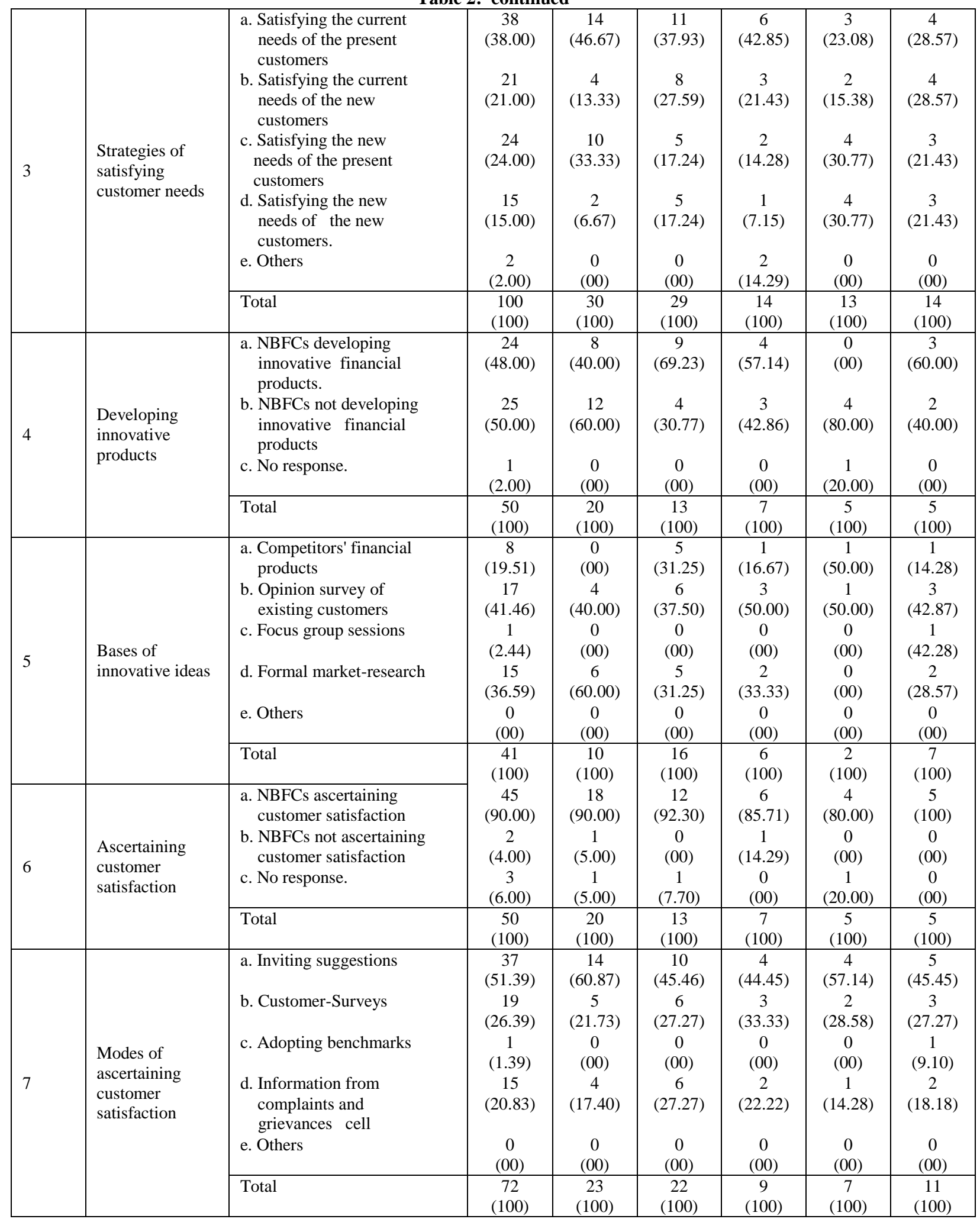

Note: Figures in the brackets indicate percentages.

Source: Field Survey 
Table 3: Pricing of Financial Products - NBFCs' Perceptions

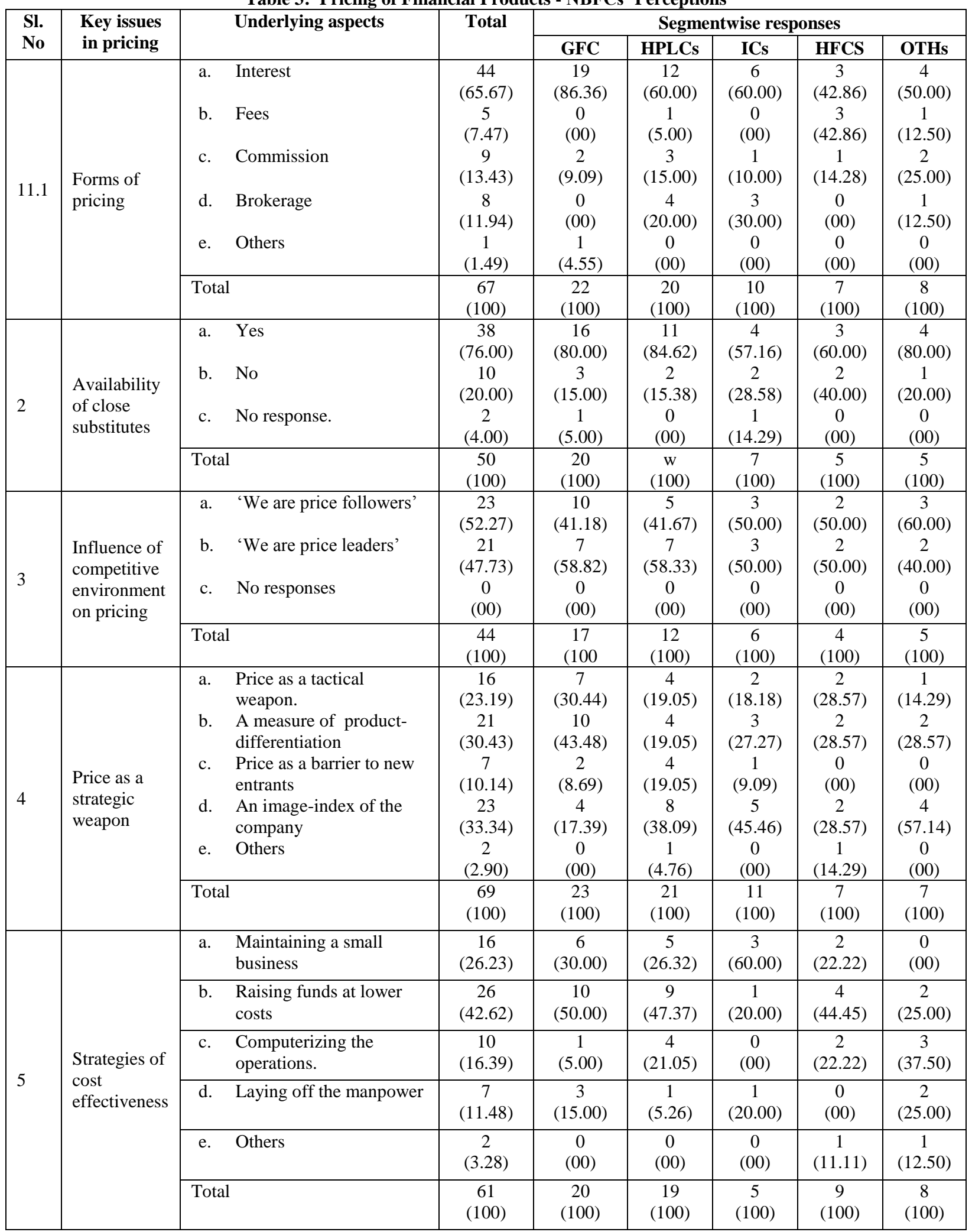

Note: Figures in the brackets indicate percentage.

Source: Field Survey 
Table 4: Pricing Factors and Objectives - NBFCs' Preferences

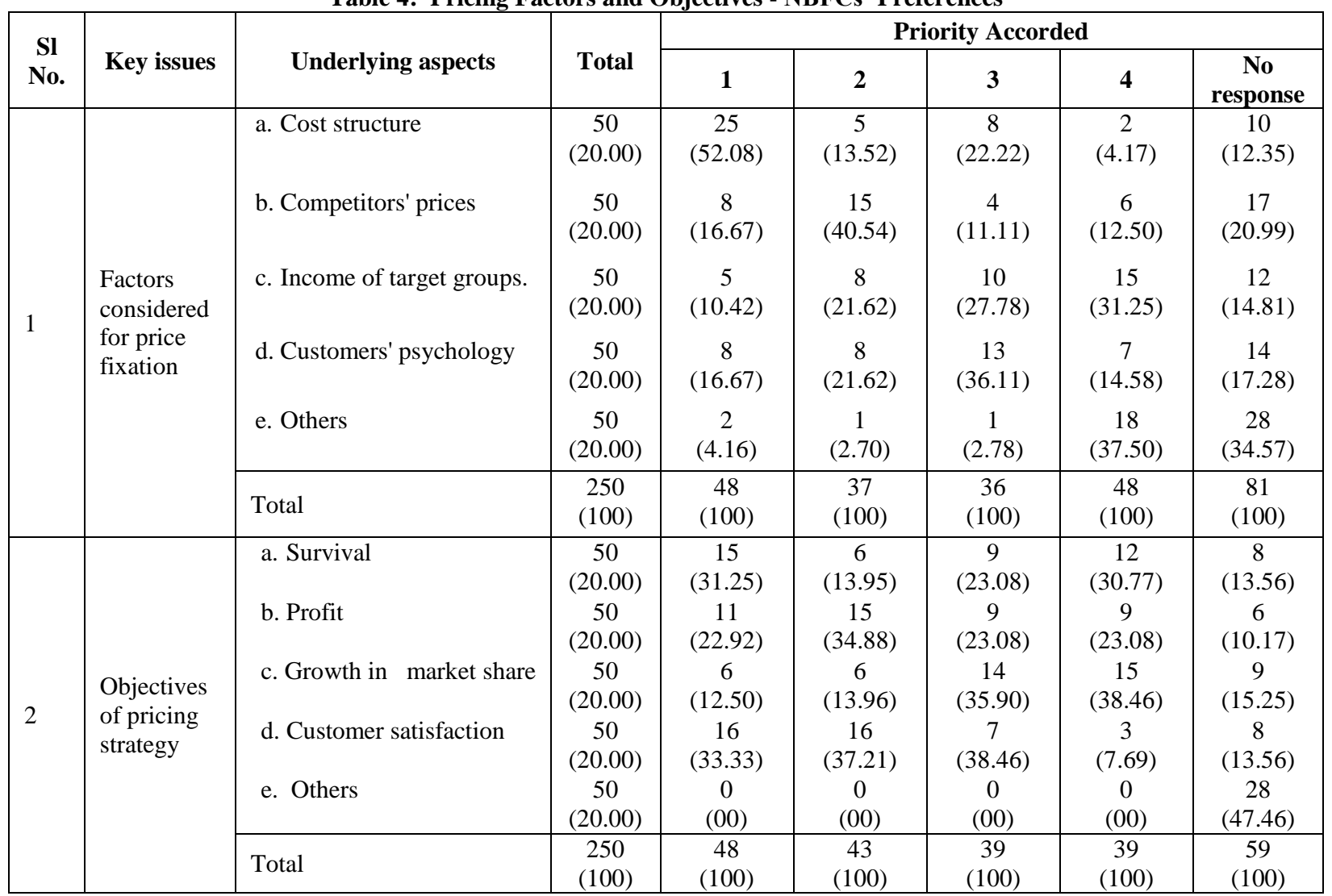

Note: Figures in the brackets indicate percentages.

Source: Field survey 